\title{
HIV infection and hepatitis B seroprevalence among antenatal clinic attendees in Niger, West Africa
}

This article was published in the following Dove Press journal:

HIVIAIDS - Research and Palliative Care

20 December 20II

Number of times this article has been viewed

\author{
Saïdou Mamadou', \\ Moussa Ide \\ Amadou Roufaï Ali Maazou² \\ Balki Aoula ${ }^{2}$ \\ Seyni Labo ${ }^{4}$ \\ Mamane Bozari ${ }^{4}$ \\ 'Laboratory of Bacteriology-Virology, \\ Faculty of Health Sciences, University \\ Abdou Moumouni, Niamey, Niger; \\ ${ }^{2}$ National Reference Laboratory \\ for STI/HIV/TB, Niamey, Niger; \\ ${ }^{3}$ Coordination Board, Inter-Sectorial \\ Program on STI/HIVIAIDS, Niamey, \\ Niger; ${ }^{4}$ National Center for Social \\ Sciences Expertise, Niamey, Niger
}

\begin{abstract}
This transversal study was suggested in order to estimate the nationwide seroprevalences of HIV infection and hepatitis B among 495 pregnant women in Niger in 2008. The study detected anti-HIV antibodies with Genscreen ${ }^{\circledR}$ Plus HIV Ag/Ab Ultra Kit (Bio-Rad; Hercules, CA), Vironostika ${ }^{\circledR}$ HIV Uni-Form II Ag/Ab (bioMérieux; Marcy-l'Etoile, France), and ImmunoComb ${ }^{\circledR}$ II HIV 1 and 2 BiSpot (Orgenics; Yavne, Israel). HBsAg was detected by Monolisa ${ }^{\circledR}$ HBsAg Ultra (Bio-Rad) and ImmunoComb ${ }^{\circledR}$ II HBsAg (Orgenics). The rates obtained were $2.02 \%$ (95\% confidence intervals (CI): $1.03 \%-3.81 \%$ ) and $16.16 \%(95 \% \mathrm{CI}$ : $13.09 \%-19.77 \%$ ), respectively. There were no significant variations according to environment, region, age, marital status, educational level, antecedent of surgery and transfusion. But these data need a large sample, and periodic updates for a better planning of activities in the framework of a national reproductive health program, including prevention of mother-to-child HIV transmission.
\end{abstract}

Keywords: HIV, HBV, seroprevalence, pregnant women, Niger

\section{Introduction}

Human immunodeficiency virus (HIV) infection and hepatitis are common vertically communicable diseases, with relatively high prevalence in sub-Saharan Africa. The Joint United Nations Programme on HIV/AIDS (UNAIDS) reported 22.4 million infected persons in this area, representing $67 \%$ of the total global cases in $2008 .{ }^{1}$ Over 2 billion people have evidence of previous hepatitis B virus (HBV) infection and 350 million have become chronic carriers of the virus with 60 million of them residing in Africa. ${ }^{2}$ The correlation between chronic HBV infection and hepatocellular carcinoma (HCC) has been proven both experimentally and epidemiologically. ${ }^{3,4}$

For the two diseases, few reported data are available from Niger, a country located between Algeria and Nigeria, with 1.267 million square kilometers for only 15 million inhabitants. The main objective of this study was to generate nationwide data to aid the planning of appropriate activities for the prevention of mother-to-child HIV transmission, and national reproductive health programs.

\section{Material and methods}

\section{Sampling method}

The size of the representative sample was estimated in agreement with statistical constraints, and taking account with eventual refusal cases, insufficiently impregnated filter paper, and those with missing information. Pregnant women attending antenatal clinics were sourced from mother and infant health services, chosen for their 
high frequentation, in each region. Those who declined to participate in the study were not replaced.

\section{Data collection}

Every eligible woman was asked to answer questions about demographic data, education level, and antecedent of surgery or blood transfusion. Standardized questionnaires were filled in by the investigators (midwifes). A code number was used to identify study participants. After finger pricking with sterile disposable safety lancets, blood was collected on calibrated spots of filter paper (Serobuvard ${ }^{\circledR}$ LDA22; Ploufragan, France). The blood spots were left to dry at ambient temperature; then the dried blood spots (DBS) were placed in paper envelopes for transport to a laboratory by the supervisors of the survey.

\section{Laboratory method}

Briefly, after overnight incubation of the DBS, the eluates were used for the screening of the different markers. For HIV infection, the study used Genscreen ${ }^{\circledR}$ Plus HIV Ag/Ab Ultra Kit (Bio-Rad; Hercules, CA) first. Negative specimens were then definitely considered as corresponding to noninfected individuals. Positive specimens were tested with Vironostika ${ }^{\circledR}$ HIV Uni-Form II Ag/Ab (bioMérieux; Marcy-1'Etoile, France); negative results were considered as definitive while positive results were later tested with ImmunoComb ${ }^{\circledR}$ II HIV 1 and 2 BiSpot (Orgenics; Yavne, Israel) to discriminate HIV-1 and HIV-2. HBsAg was detected by Monolisa ${ }^{\circledR}$ HBsAg Ultra (Bio-Rad) and ImmunoComb ${ }^{\circledR}$ II HBsAg (Orgenics).

\section{Data analysis}

Data analysis was performed with Epi Info ${ }^{\text {TM }} 6$ software (Centers for Disease Control and Prevention (CDC); Atlanta, GA). Confidence intervals (CI) were calculated by using the Fleiss quadratic method. ${ }^{5}$ Pearson's $\mathrm{X}^{2}$ and Fisher's exact tests were used whenever appropriate (a $P$-value $<0.05$ was considered significant).

\section{Ethical aspects}

Informed oral consent was obtained from study participants after an explanation of the aims and methods of the survey that included unequivocal reference to HIV testing and the assurance that no individual results could be generated by the study design. Collected data were anonymous and unlinked. Women were strongly encouraged to accept the routine antenatal HIV infection and syphilis screening.

\section{Results}

Five hundred and eight pregnant women were asked to participate, of which, 506 accepted and were tested; the refusal rate was $0.39 \%$. Eleven women were not tested because of insufficiently impregnated filter papers and/or missing information. The final size of the sample was 495 women.

The overall seroprevalence was 2.02\% (95\% CI: $1.03 \%-$ $3.81 \%$ ) for HIV and $16.16 \%$ (95\% CI: $13.09 \%-19.77 \%$ ) for hepatitis B. Three cases of coinfection HIV-HBV were found. All HIV strains were type 1.

As presented in Tables 1 and 2, there were no significant variations of HIV infection rate according to environment $(P=0.814)$; region $(P=0.619)$; age $(P=0.907)$; marital status $(P=0.780)$; or educational level $(P=0.738)$. Also, variations were not significant for $\mathrm{HBV}$ according to environment $(P=0.616)$; region $(P=0.999)$; age $(P=0.997)$; marital status $(P=0.618)$; educational level $(P=0.584)$; history surgery $(P=0.703)$; or blood transfusion $(P=0.953)$.

\section{Discussion}

HIV seroprevalence in the general population of Niger was $0.9 \%$ in 2002 and $0.7 \%$ in $2006 .^{6,7}$ Two previous HIV serosurveys among pregnant women were conducted the same

Table I Seroprevalence of the two markers according to environment, region, and age of 495 pregnant women

\begin{tabular}{|c|c|c|c|c|c|}
\hline \multirow[t]{2}{*}{ Feature } & \multirow[t]{2}{*}{ Number } & \multicolumn{2}{|l|}{ HIV } & \multicolumn{2}{|c|}{ HBsAg } \\
\hline & & + & Prevalence & + & Prevalence \\
\hline \multicolumn{6}{|c|}{ Environment } \\
\hline Urban & 241 & 5 & $2.07 \%$ & 42 & $17.01 \%$ \\
\hline Rural & 254 & 5 & $1.97 \%$ & 38 & $15.35 \%$ \\
\hline$P$ value & & 0.814 & & 0.616 & \\
\hline \multicolumn{6}{|l|}{ Region } \\
\hline Agadez & 68 & I & $1.47 \%$ & 11 & $16.17 \%$ \\
\hline Diffa & 26 & 0 & $0 \%$ & 4 & $15.38 \%$ \\
\hline Dosso & 67 & 2 & $2.98 \%$ & 10 & $14.93 \%$ \\
\hline Maradi & 61 & I & $1.64 \%$ & 9 & $14.75 \%$ \\
\hline Niamey & 73 & 0 & $0 \%$ & 12 & $16.43 \%$ \\
\hline Tahoua & 68 & 2 & $2.94 \%$ & 12 & $17.65 \%$ \\
\hline Tillaberi & 61 & 0 & $0 \%$ & 10 & $16.39 \%$ \\
\hline Zinder & 71 & 4 & $5.63 \%$ & 12 & $16.90 \%$ \\
\hline$P$ value & & 0.619 & & 0.999 & \\
\hline \multicolumn{6}{|c|}{ Age (years) } \\
\hline $15-19$ & 84 & 3 & $3.57 \%$ & 13 & $15.48 \%$ \\
\hline $20-24$ & 147 & 3 & $2.04 \%$ & 24 & $16.33 \%$ \\
\hline $25-29$ & 125 & 3 & $2.4 \%$ & 20 & $16 \%$ \\
\hline $30-34$ & 54 & I & $1.85 \%$ & 8 & $14.81 \%$ \\
\hline $35-39$ & 39 & 0 & $0 \%$ & 7 & $17.95 \%$ \\
\hline $40-44$ & 44 & 0 & $0 \%$ & 8 & $18.18 \%$ \\
\hline $45-49$ & 2 & 0 & $0 \%$ & 0 & $0 \%$ \\
\hline$P$ value & & 0.907 & & 0.997 & \\
\hline
\end{tabular}


Table 2 Seroprevalence of the two markers according to marital status, educational level, antecedent of surgery and blood transfusion for 495 pregnant women

\begin{tabular}{|c|c|c|c|c|c|}
\hline \multirow[t]{2}{*}{ Feature } & \multirow[t]{2}{*}{ Number } & \multicolumn{2}{|l|}{ HIV } & \multicolumn{2}{|c|}{ HBsAg } \\
\hline & & + & Prevalence & + & Prevalence \\
\hline \multicolumn{6}{|c|}{ Marital status } \\
\hline Monogamous & 297 & 6 & $2.02 \%$ & 46 & $15.49 \%$ \\
\hline Polygamous & 192 & 4 & $2.08 \%$ & 33 & $17.19 \%$ \\
\hline Divorced & 6 & 0 & $0 \%$ & 1 & $16.67 \%$ \\
\hline$P$ value & & 0.780 & & 0.618 & \\
\hline \multicolumn{6}{|c|}{ Education level } \\
\hline None & 312 & 7 & $2.24 \%$ & 49 & $15.70 \%$ \\
\hline Primary/ & 135 & 3 & $2.22 \%$ & 25 & $18.52 \%$ \\
\hline \multicolumn{6}{|l|}{ Koranic } \\
\hline \multicolumn{6}{|l|}{ school } \\
\hline Secondary/ & 48 & 0 & $0 \%$ & 6 & $12.25 \%$ \\
\hline \multicolumn{6}{|l|}{ High } \\
\hline \multicolumn{6}{|l|}{ school } \\
\hline$P$ value & & 0.738 & & 0.584 & \\
\hline \multicolumn{6}{|l|}{ Surgery } \\
\hline Yes & 7 & 0 & $0 \%$ & 1 & $14.29 \%$ \\
\hline No & 488 & 10 & $2.05 \%$ & 79 & $16.19 \%$ \\
\hline$P$ value & & _- & & 0.703 & \\
\hline \multicolumn{6}{|c|}{ Blood transfusion } \\
\hline Yes & 16 & 0 & $0 \%$ & 2 & $12.50 \%$ \\
\hline No & 479 & 10 & $2.09 \%$ & 78 & $16.28 \%$ \\
\hline$P$ value & & - & & 0.953 & \\
\hline
\end{tabular}

years, in three administrative regions within the UNFPA program, and one site by region. The overall rates reported were $0.96 \%(95 \% \mathrm{CI}: 0.5 \%-1.7 \%)$ and $1.2 \%(95 \% \mathrm{CI}$ : $0.7 \%-2.1 \%$ ), respectively. ${ }^{8}$ The present study used a subsample from all eight regions of Niger for a better estimation of HIV seroprevalence among pregnant women in 2008. The rate of $2.02 \%$ (95\% CI: $1.03 \%-3.81 \%$ ) was not significantly different from the 2002 and 2006 rates $(P=0.196)$. HIV-1 was responsible for all cases of HIV infection in this study; these data are in agreement with the general decreasing of HIV-2 prevalences in Niger and other West African countries. ${ }^{9}, 10$ These updated data provided by the study made a useful contribution to the planning of HIV-vertical transmission prevention in the recent HIV/AIDS proposition to the Round 10 Global Fund Against AIDS, Tuberculosis and Malaria. However, the sample size of this study was relatively small for testing factors potentially relevant to HIV infection among antenatal clinic attendees in Niger.

For hepatitis B screening, HBsAg is still the main marker, despite some false-negative results caused by the rare variation in the antigenic determinant a, observed in occult hepatitis. ${ }^{11,12}$ The relatively high rate of $\mathrm{HBsAg}$ carriage among pregnant women is in agreement with the well-established hyperendemicity of HBV in sub-Saharan Africa. Previous studies reported similar levels of this marker in various groups in Niger: $17.6 \%$ among students in 1985 and HIV positive people in $2007 ; 14.46 \%$ among blood donors in 2007..$^{13-15}$ Nevertheless, no concrete measure of control has been undertaken for this vaccine-preventable disease, until September 2008 when hepatitis B vaccine was used in a routine vaccination program. Also, HBsAg detection is required in the package of antenatal biological screenings. HBV vertical transmission can be avoided by vaccinating newborns as early as possible, preferably before departure from the maternity hospital.

In conclusion, this study demonstrated that the HIV prevalence rate was enough to declare a HIV generalized epidemic in Niger, but a large scale study for data confirmation and for testing factors relevant to HIV infection among pregnant women is needed. For hepatitis B, these data clearly showed the pertinence and the necessity of considering $\mathrm{HBsAg}$ systematic screening as an important disease control strategy. This is a challenge for the national reproductive health program.

\section{Acknowledgments}

We gratefully acknowledge the following people for support of this survey: Mr Mamane Bachir Yahaya, Head of the Private Office of the President of the Republic of Niger; Dr Moussa Ide (National Coordinator) and Dr Aissatou Dieng (Technical Assistant) at Inter-Sectorial Program on STI/ HIV/AIDS; Dr Nassirou Abdoulkarim, local fund agent of the Global Fund Against AIDS, Tuberculosis and Malaria; Mr Mamane Bozari, Director of the National Centre for Social Sciences Expertise and all his field investigators.

\section{Disclosure}

The authors report no conflicts of interest in this work.

\section{References}

1. Joint United Nations Programme on HIV/AIDS (UNAIDS). 2009 AIDS Epidemic Update. Geneva, Switzerland: UNAIDS and World Health Organization. Available from: http://www.unaids.org/en/media/unaids/ contentassets/dataimport/pub/report/2009/jc1700_epi_update_2009_ en.pdf. Accessed November 27, 2011.

2. Lee WM. Hepatitis B virus infection. $N$ Engl J Med. 1997;337(24): 1733-1745.

3. Brechot C, Pourcel C, Louise A, et al. Presence of integrated hepatitis $B$ virus DNA sequences in cellular DNA of human hepatocellular carcinoma. Nature. 1980;286(5772):533-535.

4. Beasley RP, Hwang LY, Lin CC, et al. Hepatocellular carcinoma and hepatitis B virus. A prospective study of 22707 men in Taiwan. Lancet. 1981;2(8256):1129-1133.

5. Fleiss JL. Statistical Methods for Rates and Proportions. 2nd ed New York: John Wiley and Sons 1981;14-15. 
6. Boisier P, Ouwe Missi Oukem-Boyer ON, Amadou HA, et al. Nationwide HIV prevalence survey in general population in Niger. Trop Med Int Health. 2004;9(11):1161-1166.

7. Mamadou S, Cisse RM, Ali MAR, et al. Séroprévalence de l'infection à VIH en population générale au Niger en 2006 [HIV infection seroprevalence in general population in Niger in 2006]. Annales de l'Université Abdou Moumouni. 2010;11(Tome XI-A):20-23. [French.]

8. Tohon Z, Mamadou S, Mainassara HB, et al. HIV seroprevalence surveys in Nigerien pregnant women: a comparison between 2002 and 2006. Trans R Soc Trop Med Hyg. 2007;101(11):1101-1105.

9. Ousseini H, Pecarrere JL, Meynard D, et al. Evolution de la séroprévalence des infections à VIH1 et VIH2 à l'Hôpital National de Niamey, Niger [Evolution of the seroprevalence of HIV-1 and HIV-2 infections in the national hospital of Niamey, Niger]. Bull Soc Pathol Exot. 1991;84(3):235-239. [French.]

10. Marlink R. Lessons from the second AIDS virus, HIV-2. AIDS. 1996; 10(7):689-699.

11. Jongerius JM, Wester M, Cuypers HT, et al. New hepatitis B virus mutant form in a blood donor that is undetectable in several hepatitis B surface antigen screening assays. Transfusion. 1998;38(1):56-59.
12. Torbenson M, Thomas DL. Occult hepatitis B. Lancet Infect Dis. 2002;2(8):479-486.

13. Soubiran G, Le Bras M, Marini P, et al. High HBsAg and anti-delta carrier rate among asymptomatic Africans living on the campus of the University of Niamey, Niger. Trans R Soc Trop Med Hyg. 1987;81(6): 998-1000.

14. Mamadou S, Idé M, Gagara H, et al. Séroprévalence des hépatites B et $\mathrm{C}$ chez les personnes vivant avec le VIH au Niger [Hepatitis B and C seroprevalence among people living with HIV/AIDS in Niger]. Journal de la Société de Biologie Clinique. 2009;013:42-44. [French.]

15. Mamadou S, Rabo S, Ali Maazou AR, et al. Séroprévalence des virus de l'immunodéficience humaine, des hépatites $\mathrm{B}$ et $\mathrm{C}$ chez les donneurs de sang de Niamey en 2007 [HIV infection, hepatitis B and C seroprevalence among blood donors of Niamey in 2007]. Annales de l'Université Abdou Moumouni. 2010;11(Tome A):28-31. [French.]

\section{Publish your work in this journal}

HIV/AIDS - Research and Palliative Care is an international, peerreviewed open-access journal focusing on advances in research in HIV, its clinical progression and management options including antiviral treatment, palliative care and public healthcare policies to control viral spread. The journal welcomes original research, basic science, clinical \& epidemiological studies, reviews \& evaluations, expert opinion \& commentary, case reports \& extended reports. The manuscript management system is completely online and includes a very quick and fair peer-review system. Visit http://www.dovepress.com/ testimonials.php to read real quotes from published authors. 